\title{
ANALISIS PENGEMBANGAN ELECTRONIC GOVERNMENT DI KOTA TEGAL
}

\author{
Thalita Rifda Khaerani ${ }^{1)}$ Melsy Vanesa Sarai ${ }^{2)}$ \\ Fakultas IImu Sosial dan IImu Politik, Universitas Mulawarman \\ thalitarifdakhaerani@fisip.unmul.ac.id
}

\begin{abstract}
Abstrak
Penerapan e-government pada suatu daerah mengacu Undang-Undang No. 32 tahun 2004 tentang pemerintah daerah yang menjadi legitimasi bagi dilaksanakannya otonomi daerah. Maka dari itu, pembangunan pemerintahan yang direncanakan harus ada alat kontrol bersama yang transparan agar pemerintahan yang dibangun dapat berjalan dengan mengutamakan kepentingan publik. Dalam hal ini e-government tampaknya bisa dijadikan alternatif untuk melaksanakan tugas dengan baik khususnya pada sektor pelayanan. Untuk itu diperlukan upaya pengembangan egovernment di Kota Tegal dalam rangka mendukung smart city di Kota Tegal. Penelitian ini bertujuan untuk menganalisis pengembangan berdasarkan tiga elemen-elemen sukses e-government di pemerintah kota tegal serta faktor-faktor yang menjadi penentu dalam tingkat kesiapan egovernment di kota tegal. Jenis penelitian adalah penelitian desktriptif kualitatif dengan teknik pemilihan informan secara purposive, teknik koleksi data berupa observasi, wawancara mendalam, dokumentasi dan studi pustaka beserta teknik analisis data berupa reduksi data, penyajian data dan menarik kesimpulan. Hasil penelitian yang diperoleh bahwa dalam penerapan e-government dari segi kualitas sumber daya manusia sudah memadai kemudian dalam pelaksanaannya sudah berjalan dengan baik. Namun dalam pelaksanaannya masih terdapat kekurangan-kekurangan yang mengakibatkan pelaksanaannya menjadi kurang maksimal yaitu dari segi regulasi, infrastruktur maupun kekurangan sumber daya manusia.
\end{abstract}

Kata Kunci: electronic government, e-gov, pengembangan e-government

\begin{abstract}
The application of e-government to an area referred to Legislation No. 32 in 2004 the legitimacy of territory administration. Hence, the construction of a government that is supposed to have transparent joint controls in order for a government to be built to run with public interests. In this case the e-government would appear to be an alternative to doing well, especially in the service sector. Therefore e-government development efforts in the City of Tegal are required in support of smart city in the City of Tegal. The study aims to analyze development based on three successful e-government elements in the city's tegal government as well as factors that determine egovernment readiness levels in the city's tegal. The kind of research is qualitative desktop research with information-selection techniques, data collection techniques of observation, in-depth interviews, documentation and library studies and data analysis techniques of data reduction, presentation of data and drawing conclusions. Studies obtained that in the application of the egovernment in terms of the quality of human resources are adequate, and then the administration is well executed. But in the process there is still a shortage which makes the implementation less maximum. Which is in a regulatory way, infrastructure, nor the lack of human resource.
\end{abstract}

Keyword: electronic government, e-gov, e-government development 


\section{A. PENDAHULUAN}

Legitimasi terlaksananya program otonomi daerah yang tertuang di dalam Undang-Undang No. 32 tahun 2004 tentang Otonomi daerah yang menjadi acuan dalam menciptakan perubahan-perubahan dalam suatu daerah dengan pemanfaatan teknologi komunikasi dan informasi dalam proses pemerintahan yang diyakini akan meningkatkan efisiensi, efektifitas, transparansi serta akuntabilitas dalam penyelenggaraan pemerintahan. Otonomi daerah muncul dari adanya tuntutan perubahan pembagian kewenangan yang lebih besar untuk mengelola pemerintahan di daerah. Dengan adanya otonomi daerah ini juga diharapkan untuk menstimulan kemandirian dan kreatifitas dalam mengembangkan wilayah. Maka pada saat itu juga, perubahan yang ada di dalam teknologi juga harus dikembangkan dan digunakan oleh para administrator untuk mengutamakan kepentingan publik(Indrajit, 2004:2). E-government atau sering disingkat e-gov meupakan sistem baru yang hadir dalam mengatasi dinamika perubahan di dalam birokrasi E-gov merupakan pemanfaatan teknologi yang dapat menunjang tercapainya pelaksanaan tugas pemerintahan secara baik.

Kota Tegal merupakan salah satu kota di Jawa Tengah memiliki banyak potensi yang dapat dikembangkan untuk meningkatkan perekenomian. Kota Tegal yang terletak di jalur pantura yang merupakan jalur utama barang dan jasa di Jawa. Dasar hukum terkait kepemilikan email setiap instansi Pemerintah Kota Tegal melalui keputusan Walikota Tegal Nomor: 556/102/2013 tentang Alamat E-mail Resmi Pemerintah Kota Tegal. Pembuatan e-mail tersebut bertujuan untuk meningkatkan hubungan kerja antar instansi pemerintah dan pelayanan kepada masyarakat secara efektif dan transparan dengan memanfaatkan teknologi dan informasi. Namun dalam pelaksanaannya tidak ada kejelasan mengenai Standard Operational Procedure (SOP) yang diberikan terkait penggunaan fasilitas e-mail tersebut oleh masyarakat jika membutuhkan informasi maupun menyampaikan saran dan keluhan kepada SKPD setempat.

Volume 8 | Nomor 3 | Edisi Desember 2020 | JIA
Meskipun pemerintah Kota Tegal sudah memiliki website resmi sendiri namun tidak semua SKPD memiliki website remis yang dapat diakses oleh masyarakat. Informasi yang terdapat di dalam website resmi pemerintah kota Tegal tersebut pun masih bersifat umum dan kurang up to date dalam memberikan gambaran secara detail mengenai potensi yang dimiliki Kota Tegal serta tidak disediakannya ruang bagi publik untuk mengakses informasi serta melakukan tanya jawab secara langsung melalui media online tersebut sehingga tidak dapat diakses secara mudah, cepat, transparan, dan akuntabel oleh masyarakat secara luas. Maka dari itu, diperlukan adanya kajian mengenai penerapan electronic government di Kota Tegal sebagaimana tercantum dalam Visi Kota Tegal 2014-2019, yaitu: Terwujudnya Kota Tegal yang Sejahtera dan Bermartabat Berbasis Pelayanan Prima. Adapun tujuan dari penulisan ini yaitu Menjelaskan analisis pengembangan electronic government di Kota Tegal dan Menganalisis faktor-faktor penentu tingkat kesiapan electronic government di Kota Tegal.

Handoko (2003: 10) mengungkapkan bahwa manajemen adalah bekerja dengan orang-orang untuk menentukan, menginterpretasikan dan mencapai tujuantujuan organisasi dengan pelaksanaan fungsi-fungsi perencanaan, pengorganisasian, penyusunan personalia, pengarahan, kepemimpinan dan pengawasan. Sedangkan Hasibuan (2000: 2) menguraikan bahwa manajemen adalah ilmu dan seni mengatur proses pemanfaatan sumber daya manusia dan sumber-sumber lainnya secara efektif dan efisien untuk mencapai satu tujuan.

Manajemen, menurut Terry (2009: 9) mencakup kegiatan untuk mencapai tujuan, dilakukan oleh individu-individu yang menyumbangkan upayanya yang terbaik melalui tindakan-tindakan yang telah ditetapkan sebelumnya. Hal tersebut meliputi pengetahuan tentang apa yang harus mereka lakukan, menetapkan cara bagaimana melakukannya, memahami bagaimana mereka harus melakukannya dan mengukur efektivitas dari usaha-usaha mereka. Selanjutnya, perlu menetapkan dan memelihara pula suatu kondisi lingkungan 
yang memberikan responsi ekonomis, psikologis, sosial, politis, dan sumbangansumbangan teknis serta pengendaliannya.

Terry (2009: 10-11) lebih lanjut mengungkapkan bahwa manajemen merupakan suatu ilmu dan seni. Ada wadah pengetahuan tentang manajemen yang terorganisir; ada ilmu pengetahuan yang menjelaskan bahwa manajemen dapat dibuktikan kebenarannya secara umum. Seni manajemen menuntut suatu kreativitas yang didasarkan pada kondisi pemahaman ilmu manajemen. Dengan demikian, ilmu dan seni manajemen saling mengisi.

1. Fungsi Manajemen adalah berfungsi untuk melaksanakan kegiatan-kegiatan yang perlu dilaksanakan dalam rangka pencapaian tujuan dalam batas kebijakan umum yang telah dirumuskan. (Siagian, 2003: 5). Terry (2009: 17-18) menguraikan fungsi-fungsi utama dalam manajemen, yaitu:

a. Planning ialah menetapkan pekerjaan yang harus dilaksanakan oleh kelompok untuk mencapai tujuan yang digariskan. Planning mencakup kegiatan pengambilan keputusan karena termasuk pemilihan alternatifalternatif keputusan. Diperlukan kemampuan untuk mengadakan visualisasi dan melihat ke depan guna merumuskan suatu pola dari himpunan tindakan untuk masa mendatang.

b. Organizing mencakup: Membagi komponen-komponen kegiatan yang dibutuhkan untuk mencapai tujuan ke dalam kelompok-kelompok, Membagi tugas kepada seorang manajer untuk mengadakan pengelompokan tersebut; dan Menetapkan wewenang di antara kelompok atau unit-unit organisasi. Pengorganisasian berhubungan erat dengan manusia sehingga pencaharian dan penugasannya ke dalam unit-unit organisasi sebagai bagian dari unsur organizing. Di dalam setiap kejadian, pengorganisasian melahirkan peranan kerja dalam struktur formal dan dirancang untuk memungkinkan manusia bekerja sama secara efektif guna mencapai tujuan bersama.

c. Actuating atau disebut juga "gerakan aksi" mencakup kegiatan yang dilakukan seorang manajer untuk mengawali dan melanjutkan kegiatan yang ditetapkan oleh unsur perencanaan dan pengorganisasian agar tujuan-tujuan dapat tercapai. Actuating mencakup penetapan dan pmuasan kebutuhan manusiawi dari pegawai-pegawainya, memberi penghargaan, memimpin, mengembangkan, dan memberi kompensasi kepada mereka.

d. Controlling mencakup kelanjutan tugas untuk melihat apakah kegiatan-kegiatan dilaksanakan sesuai rencana. Pelaksanaan kegiatan dievaluasi dan penyimpangan-penyimpangan yang tidak diinginkan diperbaiki supaya tujuan-tujuan dapat tercapai dengan baik. Ada berbagai cara untuk mengadakan perbaikan, termasuk merubah rencana dan bahkan tujuannya, mengatur kembali tugastugas atau merubah wewenang; tetapi seluruh perubahan tersebut dilakukan melalui manusianya. Orang yang bertanggung jawab atas penyimpangan yang tidak diinginkan itu harus dicari dan mengambil langkah-langkah perbaikan terhadap hal-hal yang sudah atau akan dilaksanakan.

Definisi Electronic Government (E-Gov) dari berbagai ahli, dalam Indrajit (2004: 2-4) antara lain: Bank Dunia mendefinisikan egovernment sebagai berikut: "E-Government refers to the use by government agencies of information technologies (such as Wide Area Network, the Internet, and mobile computing) that have the ability to transform relations with citizens, businesses, and other arms of government." United Nation Development Programme (UNDP) mendefinisikan egoverment secara lebih sederhana, yaitu: " $E$ government is the application of the Information and Communication Technology (ICT) by government agencies".

Instruksi Presiden Nomor 3 Tahun 2003 tentang Kebijakan dan Strategi Nasional Pengembangan Electronic Government menyatakan bahwa Pengembangan egovenrment merupakan upaya untuk mengembangkan

kepemerintahan penyelenggaraan
yang berbasis (menggunakan) elektronik dalam rangka meningkatkan kualitas layanan publik secara efektif dan efisien. Melalui pengembangan egov dilakukan penataan sistem manajemen dan proses kerja di lingkungan pemerintah dengan mengoptimasikan pemanfaatan teknologi informasi. Pemanfaatan teknologi 
informasi tersebut mencakup 2 (dua) aktivitas yang berkaitan, yaitu :

1. Pengolahan data, pengelolaan informasi, sistem manajemen dan proses kerja secara elektronis;

2. Pemanfaatan kemajuan teknologi informasi agar pelayanan publik dapat diakses secara mudah dan murah oleh masyarakat di seluruh wilayah negara.

a. Elemen Sukses Pengembangan E-Gov Elemen sukses pengembangan e-gov menurut hasil kajian dan riset Harvard JKF School of Government dalam Indrajit (2004: 15-18), yaitu:

Merupakan elemen pertama dan paling krusial, karena e-government bukan hanya mengikuti trend atau menentang inisiatif yang berkaitan dengan e-government. Tanpa adanya "polical will" mustahil pembangunan e-government dapat berjalan dengan baik karena budaya birokrasi cenderung bergerak berdasarkan model manajemen "top down". Yang dimaksud dengan dukungan di sini juga bukanlah hanya pada omongan semata, namun lebih jauh lagi dukungan yang diharapkan adalah dalam bentuk hal-hal sebagai berikut:

a) Disepakatinya kerangka e-government sebagai salah satu kunci sukses negara dalam mencapai visi dan misi bangsanya, sehingga harus diberikan prioritas tinggi.

b) Disosialisasikannya konsep e-government secara merata, kontinyu, konsisten, dan menyeluruh kepada seluruh kalangan birokrat secara khusus dan masyarakat secara umum melalui berbagai cara kampanye yang simpatik.

Unsur kemampuan atau keberdayaan dari pemerintah setempat dalam mewujudkan "impian" e-government terkait menjadi kenyataan. Ada tiga hal yang harus dimiliki oleh pemerintah sehubungan dengan elemen ini, yaitu:

a) Ketersediaan sumber daya yang cukup untuk melaksanakan berbagai inisiatif $e-$ government, terutama yang berkaitan dengan sumber daya finansial;

b) Ketersediaan infrastruktur teknologi informasi yang memadai, hal ini merupakan $50 \%$ dari kunci keberhasilan penerapan e-gov; dan

c) Ketersediaan sumber daya manusia yang memiliki kompetensi dan keahlian yang dibutuhkan agar penerapan e-government dapat sesuai dengan azas manfaat yang diharapkan.

Volume 8 | Nomor 3 | Edisi Desember 2020 | JIA
Elemen pertama dan kedua dilihat dari sisi pemerintah sebagai pihak pemberi jasa (supply side). Berbagai inisiatif egovenrment tidak akan ada gunanya jika tidak ada pihak yang merasa diuntungkan dalam implementasi konsep tersebut. Dan yang menentukan besar tidaknya manfaat yang diperoleh dengan adanya e-gov bukan kalangan pemerintah sendiri, melainkan masyarakat dan yang berkepentingan (demand side). Untuk itulah maka pemerintah harus benar-benar teliti dalam memilih prioritas jenis aplikasi e-government apa saja yang harus didahulukan pembangunannya agar benar-benar memberikan value (manfaat) yang secara signifikan dirasakan oleh masyarakatnya.

Indrajit, 2005:8-9 mengemukakan faktor-faktor penentu yang ikut menjadi pertimbangan dalam menentukan tingkat kesiapan sebuah daerah menetapkan e-gov, yaitu:

1) Infrastruktur telekomunikasi, dalam pelaksanaannya perangkat keras seperti komputer, jaringan, infrastruktur akan menjadi faktor teramat sangat penting dalam penerapan e-government. Secara ideal memang harus tersedia infrastruktur yang menunjang target atau prioritas pengambangan e-government yang telah disepakati.

2) Tingkat konektivitas dan penggunaan $\mathrm{TI}$ oleh pemerintah, dengan mengamati sejauh mana pemerintah saat ini menerapkan beraneka ragam teknologi informasi dalam membantu kegiatan sehari-hari akan tampak sejauh mana kesiapan dalam menerapkan egovernment.

3) Kesiapan sumber daya manusia di pemerintah, SDM merupakan subyek dalam inisiatif e-government dalam pemerintahan sehingga tingkat kompetensi dan keahlian akan mempengaruhi penerapan e-government.

4) Ketersediaan dana dan anggaran, pemerintah daerah harus memiliki jaringan yang cukup mengenai sumber daya finansial untuk membiayainya.

5) Perangkat hukum, konsep e-government terkait dengan usaha penciptaan dan pendistribusian data/informasi dari suatu pihak terhadap pihak lain, masalah keamanan data/informasi dan hak cipta intelektual. Pemerintah harus memiliki perangkat hukum yang menjamin 
terciptanya mekanisme e-government yang kondusif.

6) Perubahan paradigma, pada hakikatnya penerapan e-government merupakan suatu proyek change management yang membutuhkan adanya keinginan untuk, mengubah paradigma dan cara berfikir. Perubahan paradigma ini akan bermuara pada dibutuhkannya kesadaran dan keinginan untuk mengubah cara kerja, bersikap, perilaku, dan kebiasaan seharihari.

\section{B. METODE PENELITIAN}

Berikut akan diuraikan mengenai halhal yang terdapat dalam metode penelitian ini Penelitian ini digunakan tipe penelitian deskriptif kualitatif karena akan menganalisis pengembangan electronic government di Kota Tegal dan faktor-faktor penentu tingkat kesiapan electronic government di Kota Tegal.

Tipe penelitian ini adalah kualitatif, untuk itu dalam penelitian ini teknik yang digunakan untuk memilih informan adalah teknik purposive. Dengan mendasarkan pada hal-hal tersebut $\mathrm{di}$ atas dan dengan mempertimbangkan situasi yang ada pada lokasi penelitian, yaitu pada Kantor Dinas Perhubungan Komunikasi dan Informatika (Dishubkominfo) Kota Tegal, maka informan yang dipilih oleh peneliti adalah pimpinan dan jajaran staff Bidang Komunikasi dan Informatika Dishubkominfo Kota Tegal yang bertanggung jawab di dalam pengelolaan $e-$ government di Kota Tegal. Sumber data dalam penelitian ini dibedakan menjadi 2 (dua) jenis, yaitu Sumber Data Primer dan Sumber Data Sekunder. Penulisan ini digunakan teknik koleksi data melalui beberapa cara sebagai berikut Observation (Pengamatan Mendalam), In-Depth Interview (Wawancara Mendalam), Dokumentasi; serta Studi Pustaka.

Teknik analisis data yang digunakan mencakup 3 (tiga) kegiatan yang bersamaan, yaitu: reduksi data, penyajian data, dan penarikan kesimpulan. Dengan pendekatan kualitatif, logika yang dibangun lebih ke arah induktif-abstraktif (Sanapiah, Faisal, dalam Burhan Bungin, 2003: 68). Metode yang dilakukan ialah menggunakan metode triangulasi sehingga antara kegiatan pengumpulan data dan analisis data menjadi tidak mungkin dipisahkan satu sama lain. Keduanya berlangsung simultan. Langkah

Volume 8 | Nomor 3 | Edisi Desember 2020 | JIA analisis data di dalam penelitian ini dilakukan melalui:

1. Pengamatan terhadap pengelolaan egovernment yang telah diterapkan di Kota Tegal. Pengamatan dilakukan secara langsung di Dishubkominfo Kota Tegal, khususnya pada Bidang Kominfo selaku penyelenggara serta pengelola e-gov di Kota Tegal.

2. Melakukan wawancara kepada key informan dan informan lainnya seputar pengembangan electronic government di Kota Tegal dan faktor-faktor penentu tingkat kesiapan electronic government di Kota Tegal.

3. Mendeskripsikan sejauh mana pengembangan electronic government di Kota Tegal dan faktor-faktor penentu tingkat kesiapan electronic government di Kota Tegal. Menarik kesimpulan berdasarkan berbagai data yang telah didapat.

\section{HASIL DAN PEMBAHASAN}

\section{Analisis Pengembangan Electronic Government di Kota Tegal}

Dalam hal ini, untuk menerapkan konsep-konsep digitalisasi pada sektor publik, terdapat tiga elemen sukses yang harus dimiliki dan diperhatikan yaitu Support, Capacity dan Value.

\section{Support}

Pada elemen pertama, Bentuk support merupakan kunci utama yang harus dimiliki Pemerintah Kota Tegal. dalam penerapan e-government di Kota Tegal yaitu mengacu pada peraturan perundangan atau regulasi yang digunakan sebagai dasar penerapan egov, antara lain sebagai berikut:

1) Istruksi Presiden Nomor: 3 Tahun 2003 tentang Kebijakan dan Strategi Nasional Pengembangan Egovernment

2) Peraturan Menteri Komunikasi dan Informatika Nomor: 2/PER/M.KOMINFO/12/2010 tetang Standar Pelayanan Minimal Bidang Komunikasi dan Informatika di Kabupaten/Kota

3) Peraturan Daerah Kota Tegal Nomor: 11 Tahun 2008 tentang Organisasi dan Tata Kerja Dinas Daerah Kota Tegal 
4) Keputusan Walikota Tegal Nomor: 555.6/166/2010 tentang Penetapan Nama Domain untuk Situs Web Resmi Kota Tegal

5) Keputusan Walikota Tegal Nomor: 556/102/2013 tentang Alamat E-mail Resmi Pemerintah Kota Tegal

Meskipun peraturan ini telah ditetapkan, kebijakan daerah mengenai SPM di Bidang Komunikasi dan Informatika Kepala Seksi Bidang Komunikasi dan Informatika mengatakan bahwa tidak adanya regulasi yang mengatur tentang e-gov secara keseluruhan yang masih bersifat parsial, maka dari itu dalam perencanaannya Pemerintah Kota Tegal masih menyusun regulasi terkait e-gov ini yaitu berupa Peraturan Walikota tentang Tata Kelola Teknologi Informasi dan Komunikasi atau Peraturan Walikota TIK yang diharapkan menjadi acuan bagi para stakeholder untuk bertindak sesuai dengan aturan yang ada.

\section{Capacity}

Pada elemen kedua dilihat dari aspek Capacity kualitas sumber daya manusia juga menjadi komponen penting dalam penerapan e-government . Berdasarkan hasil penelitian jumlah keseluruhan pegawai di Bagian Kominfo Dishubkominfo Kota Tegal adalah 8 (delapan) orang, yang terdiri atas: Iulusan S1 sebanyak 6 (enam) orang, lulusan SMK sejumlah 2 (dua) orang. Jika dikaitkan dengan Tingkat pendidikan untuk saat ini sudah disesuaikan dengan kompetensi yang harus dimiliki pegawai Bagian Kominfo Dishubkominfo Kota Tegal kemudian disusul dengan 2 (dua) orang pegawai yang sedang menempuh S2 dalam bidang IT. Namun meskipun demikian, dalam pemenutuhan kebutuhan formasi pegawai belum seluruhnya terpenuhi terutama pemenuhan SDM dalam bidang teknis.

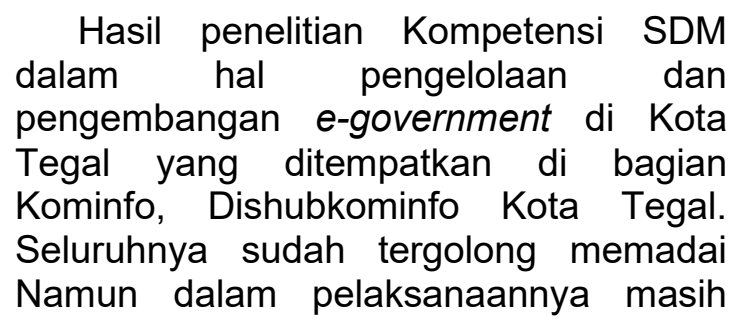

terdapat kekurangan formasi yang harus diisi oleh SDM yang berkompeten dalam bidangnya. Kekurangan formasi SDM di Bagian Kominfo karena pada saat ini hanya terdapat 3 (tiga) orang pegawai yang efektif untuk melakukan pekerjaan yang sifatnya teknis, seperti dalam hal pengelolaan server atau permasalahan infrastruktur IT lainnya. Untuk itu, masih diperlukan penambahan jumlah personil, baik untuk pemenuhan pegawai pada bagian teknis maupun untuk pemenuhan pegawai bagian nonteknis.

\section{Value}

Pada elemen ketiga dilihat dari aspek Value, dalam hal ini manfaat adanya egovernment harus dirasakan oleh kalangan masyarakat juga. Pemerintah Kota Tegal selalu mengupayakan pemenuhan kebutuhan informasi dan mengingat pentingnya penyebarluasan informasi kepada masyarakat guna mendukung e-gov dimana Pemerintah Kota Tegal telah memiliki website resmi yang dapat diakses melalui www.tegalkota.go.id dan website SKPD di Kota Tegal (domain utama: www.tegalkota.go.id; domain turunan: [nama SKPD].tegalkota.go.id) yang dapat diakses oleh stakeholder e-gov dan masyarakat sebagai pengguna secara mudah. Selain website resmi, pemerintah Kota Tegal juga menggunakan media sosial, seperti facebook sebagai sarana yang dapat digunakan untuk dapat berinteraksi langsung kepada masyarakat yang dapat diakses dengan facebook id: tegalchannel.

\section{Faktor-faktor Penentu Terhadap Tingkat Kesiapan Electronic Government di Kota Tegal}

(Indrajit, 2005:8-9) mengemukakan faktor-faktor penentu yang ikut menjadi pertimbangan dalam menentukan tingkat kesiapan sebuah daerah menetapkan egovernment, yaitu:

1) Pertama, yaitu infrastruktur telekomunikasi. Berdasarkan hasil penelitian dalam pengelolaannya e-gov di Kota Tegal tersebut ternyata belum semua dapat terpenuhi dengan baik. Kemudian dalam pengembangan konten nya terdapat standarisasi dalam pemilihan dan penggunaan perangkat lunak (software) 
dan perangkat keras (hardware) yang digunakan untuk pengaplikasian e-gov di Kota Tegal. Standarisasi dilakukan hanya untuk penggunaan koneksi internet dengan menggunakan wireless.

2) Kedua, Tingkat konektivitas dan penggunaan IT oleh pemerintah, yaitu pemerintah kota tegal terus berupaya melakukan perkembangan pada aplikasi pendukung kegiatan pemerintah sudah dilakukan di beberapa bidang, seperti: tersedianya jasa akses internet yang sudah terkoneksi $100 \%$ sebagai bagian dari upaya meningkatkan keterbukaan informasi publik, dan lain-lain.

3) Ketiga, Kesiapan sumber daya manusia di pemerintah, Dalam hal ini pemerintah kota tegal terkait kompetensi SDM pengelolaan e-gov dibagian Dishubkominfo Kota Tegal untuk saat ini sudah memadai. Adapun yang menjadi kekurangan-kekurangan yaitu terdapat kekurangan formasi yang harus diisi oleh SDM yang berkompeten dalam bidangnya ketersediaan dana dan anggaran, pemerintah daerah harus memiliki jaringan yang cukup mengenai sumber daya finansial untuk membiayainya.

4) Keempat, Perangkat hukum, Berdasarkan hasil penelitian, Pemerintah Kota Tegal masih mengacu pada peraturan perundang-undangan oleh kominfo, dan belum ada regulasi terkait e-gov secara keseluruhan. Maka dari itu, pemerintah kota tegal sedang menrencanakan untuk mengeluarkan regulasi Peraturan Walikota tentang e-gov ini.

5) Kelima, Perubahan paradigma, Dalam hal ini tingginya antusiasme pegawai pemerintah kota tegal di bidang komunikasi dan informatika. Maka dari itu dengan tingginya antusiasme para pegawai yang bertanggung jawab mengelola e-gov di Kota Tegal ini, telah menginisiasi beberapa ide dalam rangka pengembangan e-gov di Kota Tegal, antara lain: pembuatan SIM Menara, radio streaming, live video streaming, dan lain sebagainya.

\section{KESIMPULAN}

Hasil penelitian ini menyimpulkan bahwa Penerapan e-gov di Pemerintah Kota Tegal sudah cukup baik dari segi pengelolaan, namun dalam pengembangannya masih terdapat beberapa hambatan berdasarkan elemen-elemen sukses e-government yaitu sebagai berikut :

1. Support Dalam penerapan e-gov di pemerintah Kota Tegal, belum adanya regulasi terkait e-gov secara keseluruhan, maka dari itu pemerintah kota tegal dalam bidang komuniasi dan informatika masih mengandalkan regulasi tentang Standar Pelayanan Minimal oleh Kominfo.

2. Capacity Kompetensi sumber daya manusia di bidang Kominfo Dishubkominfo sudah tergolong memadai, namun Pemerintah Kota Tegal masih diperlukan penambahan personil dibagian teknis maupun non teknis yang ahli dibidangnya untuk mengatasi permasalahan infrastruktur IT maupun dalam pengelolaan server.

3. Value Dalam hal ini, Pemerintah Kota Tegal telah menggunakan media sosial seperti facebook untuk dapat digunakan sebagai sarana berinteraksi kepada masyarakat serta sebagai sarana dalam penyebarluasan informasi.

Adapun faktor penentu dalam tingkat kesiapaan e-gov Pemerintah Kota Tegal (Indrajit, 2005:8-9) yakni :

1. Berdasarkan hasil penelitian dalam pengelolaannya e-gov di Kota Tegal tersebut ternyata belum semua dapat terpenuhi dengan baik.

2. Pemerintah Kota Tegal terus berupaya melakukan perkembangan pada aplikasi pendukung kegiatan pemerintah sudah dilakukan di beberapa bidang, seperti: tersedianya jasa akses internet yang sudah terkoneksi $100 \%$ sebagai bagian dari upaya meningkatkan keterbukaan informasi publik, dan lain-lain.

3. Dalam hal ini Pemerintah Kota Tegal terkait kompetensi SDM pengelolaan $e-$ gov dibagian Dishubkominfo Kota Tegal untuk saat ini sudah memadai. Namun hanya terdapat kekurangan formasi sehingga perlu adanya penambahan pegawai yang ahli di dalam bidangnya.

4. Belum adanya regulasi terkait e-gov secara keseluruhan, Pemerintah Kota Tegal sedang merencanakan untuk menerbitkan regulasi Peraturan Walikota tentang e-gov ini agar para stakeholder dapat bertindak sesuai aturan yang ada.

5. Tingginya antusiasme para pegawai yang bertanggung jawab mengelola e-gov di Kota Tegal ini, telah menginisiasi beberapa ide dalam rangka 
pengembangan e-gov di Kota Tegal, antara lain: pembuatan SIM Menara, radio streaming, live video streaming, dan lain sebagainya.

Adapun saran dari hasil penelitian ini adalah :

1. Diperlukan pemaksimalan tentang penyusunan regulasi Peraturan Walikota tentang TIK di Kota Tegal. Dalam hal ini penyusunan regulasi perlu diutamakan agar pelaksanaan e-government dapat berjalan maksimal. Maka dengan adanya usulan ini sebaiknya segera dituangkan dalam rencana kinerja dan anggaran tahun berikutnya. Pemerintah Kota Tegal juga harus memahami dengan benar regulasi yang menjadi dasar atau landasan pengaturan e-gov tersebut sehingga penyusunan draft Peraturan Walikota tentang TIK sebagai peraturan turunan tidak menyimpang dari payung hukum atau regulasi yang telah ditetapkan sebelumnya.

2. Diperlukan adanya pelatihan DIKLAT IT yang berkesinambungan. Dalam hal ini perlu adanya pelatihan bagi pegawai dalam Bidang Komunikasi dan Informatika Pemerintah Kota Tegal agar para pegawai dapat mendalami bidangnya serta meningkatkan pengembangan e-gov di Kota Tegal baik dalam bidang teknisi, penyebarluasan informasi dan pengelolaannya.

3. Melakukan perencanaan terkait merekrut pegawai yang berlatar belakang pendidikan teknologi informasi. Dikarenakan adanya kekurangan sumber daya manusia dalam bidang komukasi dan informatika Pemerintah Kota Tegal, maka diharapkan Pemerintah Kota Tegal dapat melakukan perekrutan pegawai dengan bidang yang sesuai dengan ahlinya serta kebutuhan dalam bidang komunikasi dan informatika, agar dalam proses pengembangannya dapat berjalan dengan maksimal.

\section{E. REFERENSI}

Handoko, T. Hani.2003. Manajemen. Yogyakarta: BPFE-UGM.

Hasibuan, Malayu, S. P. 2000. Manajemen Sumber Daya Manusia. Yogyakarta: STIE YKPN.

Indiahono, Dwiyanto. Perbandingan Administrasi Publik. 2009. Yogyakarta: Gava Media.

Volume 8 | Nomor 3 | Edisi Desember 2020 | JIA
Indrajit, Richardus Eko. 2004. Electronic Government (E-Gov) (Strategi Pembangunan dan Pengembangan Sistem Pelayanan Publik Berbasis Teknologi Digital). Yogyakarta: Andi.

Indrajit, Richardus Eko, dkk. 2005. Electronic Government (E-Gov) in Action (Ragam Kasus Implementasi Sukses di Berbagai Belahan dunia). Yogyakarta: Andi

Moleong, Lexy H. 2011. Metodologi Penelitian Kualitatif. Bandung: PT. Remaja Rosdakarya.

Pasolong, Harbani. 2007. Teori Administrasi Publik. Bandung: Alfabeta.

Siagian, Sondang, P. 2003. Filsafat Administrasi. Jakarta: PT. Bumi Aksara.

Thoha, Miftah. 2008. IImu Administrasi Publik Kontemporer. Jakarta: Kencana.

Tangkilisan, Hessel Nogi S. 2003. Manajemen Modern Untuk Sektor Publik. Yogyakarta: Balairung \& co.

Wibawa, Samodra. 2009. Administrasi Negara Isu-Isu kontemporer. Yogyakarta: Graha IImu.

Sosiawan, E. A. 2015. Evaluasi Implementasi E-Government pada Situs Web Pemerintah Daerah di Indonesia: Perspektif Content dan Manajemen. In Prosiding Seminar Nasional Informatika.

Inpres No. 3 Tahun 2003 tentang Kebijakan dan Strategi Nasional Pengembangan Electronic Government (E-Gov).

http://www.tegalkota.go.id/v2/index.php/en. http://www.tegalkota.go.id/v2/index.php/kami/ daftar-informasi-publik. 